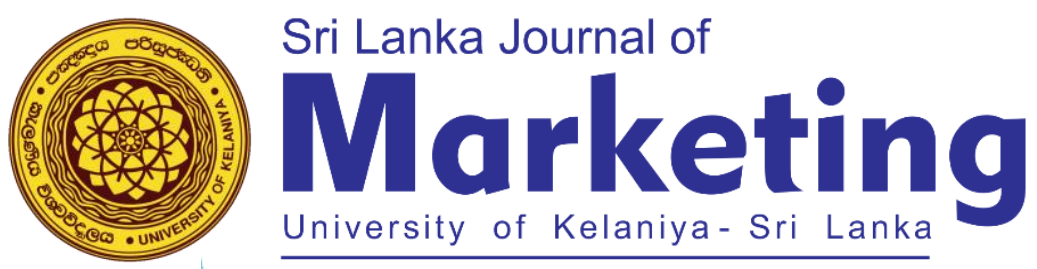

\title{
Factors Impact on Consumer Credit Card Usage Behaviour: Evidence from Sri Lanka
}

\author{
De Silva L.G.R.V. \\ Department of Marketing Management, University of Kelaniya, Sri Lanka \\ lgrvds@gmail.com \\ Patabendige S.S.J. \\ Senior Lecturer, Department of Marketing Management, University of Kelaniya, Sri Lanka \\ sugeeth@kln.ac.lk
}

\section{ABSTRACT}

Credit cards are widely popular financial product around the world which is attached to consumer's daily lifestyle. Credit cards are used for all sorts of payments by consumers based on their requirements. Consumer credit card usage is differing from person to person hence this study examines the factor's that impact on consumer credit card usage behavior in Sri Lanka. The study was conducted in the western province where the primary data for the survey was collected through a self-completed questionnaire which was distributed among 100 diverse credit card users. The sample of 100 respondents was selected through the convenient sampling technique and collected data were analyzed using a regression model and correlation analysis. This study finds a significant positive relationship between credit card attributes and credit card usage. A similar relationship was evident for social status and lifestyle variable and psychographic variable. Based on the results; credit card attributes emerged as the prominent factor impact on credit card use among Sri Lankan consumers. Further, the factors considered under this study were based on the research model developed under the conceptual framework. Whereas there are many other factors that could have influenced consumer credit card usage behavior. The findings of this study are very much helpful for the credit card issuers to structure their marketing strategies and to enhance the market share of credit card market. Similarly, this research will assist in changing the revenue structure of the credit card business.

Keywords: Consumer, Credit Card, Credit Card Attributes, Credit Card Usage, Sri Lanka 


\section{INTRODUCTION}

A credit card is a personal consumption payment card; popularly used around the world for various types of transactions. These cards were first issued in the United States in the early twentieth century and since then widely used across various transactions. According to Watkins (2000) credit cards stimulates consumer personal spending. Similarly, credit cards are considered as a personal money management platform (Garcia, 1980; Feinberg, 1986; Holt, 1997; Durkin, 2000; Hayhoe et al. 2000; Kaynak \& Harcar, 2001; Bernthal et al, 2005). Within the past few decades, credit card usage has increased substantially all over the world and became one of the most profitable financial service (Kaynak \& Harcar, 2001; Goyal, 2006). Growing personal income of consumers led to an increase in credit card use Chan (1997) as well as not required to have physical cash.

In Sri Lanka, credit cards are used to overcome financial difficulties in a given limited time frame. The credit card business in Sri Lanka demonstrates a very high growth potential. The industry is very competitive in the Sri Lankan market since all companies are providing similar products/services. It is not mandatory for the credit card holders to continue the credit card facility with the same issuer, so most consumers try to shift between credit card issuers due to benefits and offers that other competitors offered. So, there is a high risk of changing existing credit cardholders to other competitors.

There have been many types of researches carried out from different perspectives regarding Consumer credit card usage behavior Pebe et al. (2012), Jusoh \& Lin (2012), Safakli (2007) Developing economies have witnessed increased consumer spending and growth in income levels but regular use of credit cards is limited; especially in the Sri Lankan context. In previous studies carried out by many researchers discussed the general factors that influence the consumer credit card usage behavior in international market contexts covering south Asian region, Asian \& western region countries. However, there is no proper full-fledged research carried on the Sri Lankan market context of credit card usage behavior of the Consumers Understanding the lifestyle variables affecting credit cards can help companies in targeting decisions.

The key objective of this research is to determine the factors that influence on credit card usage behavior of Sri Lankan Consumers. In addition, the research study expects to examine the impact made by identified factors influencing on credit card usage behavior of Sri Lankan Consumers, to identify the most prominent factors influencing on credit card usage behavior of Sri Lankan Consumers and to critically assess the inter-relationship of each factor influencing on credit card usage behavior of Sri Lankan Consumers.

Further this research aims to test what are the factors that influence on credit card usage behavior of Sri Lankan consumers, what is the level of the impact made by identified factors influencing on credit card 
usage behavior of Sri Lankan Consumers, what is the most prominent factor influencing on credit card usage behavior of Sri Lankan Consumers and how far is the inter-relationship of each factor influencing credit card usage behavior of Sri Lankan Consumers.

Every bank that is issuing credit cards needs to analyze the credit card usage behavior of the Consumers to offer better benefits \& discounts. Also, in the meantime through analyzing the Consumer usage behavior they can promote the credit cards more aggressively by understanding Consumer touchpoints. Target Consumers can be attracted to credit cards by focusing on delivering the right value additions to the clients with conveniently. It is important for every credit card issuer needs to understand the key drivers behind credit card usage behavior to develop effective and successful marketing strategies and tactics in the business environment.

This research will assist in changing the revenue structure of the credit card business by identifying the factors influencing Consumer credit card usage behavior and thus credit card issuers can allocate more resources towards those factors in order to attract more consumers to their brands. The outcome of this research will certainly assist organizations to exploit new market opportunities and expand their market share in the domestic market. This will also enhance the knowledge of the current environment, which will help organizations to make necessary changes to current strategies and tactics. Further, the outcome of this research also serves as a database for further researchers in related fields.

\section{LITERATURE REVIEW}

\subsection{Credit Card and its Usage}

A credit card is a small plastic card (Size is $85.7 \mathrm{~mm}$ x $54 \mathrm{~mm}$ ) issued by a bank or financial institution, allowing the cardholder to purchase goods or services on credit for a specific period and there is an interest charged on credit value usage after the grace period. According to Foscht et al. (2010), credit card performs payment and credit functions where the cardholder has the benefit of paying later towards the credit card issuer (Amin, 2013). Foscht et al. (2010) also explained that at the point of transactions. credit card issuers will settle the amount to the vendors and subsequently credit cardholder needs to repay the credit card issuer.

Credit card usage has tremendously grown throughout the world; where average 5.5 credit cards per consumer are evident in United States (Durkin, 2000) and multiple credit card holding is popular among consumers in different parts of the world. According to Lee and Hogarth (1999) there are 2 types of credit card users namely convenience users and revolvers. Former category users use credit cards as a convenient payment mode and later category of users use credit cards as a financing mechanism. Further Bearden et al. (1978), Garcia (1980), Hirschman, (1979) and Kaynak \& Harcar (2001) found that credit 
card usage practices of consumers are substantially impacted through demographic and socioeconomic backgrounds.

Mathews \& Slcoum (1986) found out that social class is not the most suitable categorization for credit card users. Where they explained upper-class use credit cards for their convenience and instead of cash while lower-class use them for financing requirements. due to the evident differences in the social classes; its lead to the complex situation on offering a standard credit card for all the social classes. As examined by Kaynak \& Harcar (2001) found out that the attitudes of owners, beliefs and knowledge influence credit card usage among consumers in Turkey. Similarly, there is a relationship between credit card usage and demographic characteristics of Turkish consumers Kaynak et al. (1995) as well as countries' socioeconomic development links with credit card usage. Where advancement of consumer living standards has an impact on credit card usage.

Worthington et al. (2007) discovered that majority of the consumers in China are early adopters for credit card usage and they mostly used a credit card for travel and entertainment purposes since they realized spending through credit cards are more convenient and will add value to them. Similarly, Devlin et al. (2007) found out that Singaporeans holds one or more credit card where the main card used for an important range of transactions and subsidiary cards used for emergency and limited transactions. These consumers hold few credit cards in order to gain better discounts and loyalty rewards from various credit card issuers. Similarly, Gan et al. (2008) understood that income, gender and perception of consumer's impact on credit card usage in Singapore and requirement for frequent use for transactions relates to possession of a higher number of credit cards by consumers.

Phau \& Woo (2008) examined young Australians credit card usage behavior and money attitudes. The study revealed young Australians use credit cards more often and searching for more discounts and offers. Further these consumers' credit card usage was stimulated by portraying status and image advertising campaigns.

In current days' consumer credit is considered as a leading economic indicator where in the past it was considered as a lagging economic indicator. Consumers use credit card as a substitute for cash (Silvia, 2003) and with higher spending; the consumer debt rises substantially (Griffiths, 2000). Further it has led to compulsive buying patterns (Park \& Burns, 2005). Based on the prior literature following factors are considered as major factors that impact credit card usage behavior.

\subsection{Credit Card Attributes}

Mainly considered the convenience and use patterns as credit card attributes. Kaynak et al. (1995) discovered that credit card usage in Turkey mainly due to the convenience factor; were utilizing it as 
an emergency fund, use for foreign travel and shopping. Similarly, credit cards enable consumers to purchase products or services when lacking of physical cash (White, 1975).

According to Meidan \& Davos (1994) credit card usage in Greece depends on five factors: convenience, sense of security, personal economy, an indication of prestige and shopping abroad. Further they revealed $37 \%$ of credit card usage in Greece due to convenience factor. Therefore, they considered convenience when foreign traveling, extended credit limits and safer to use for payments as the dimensions to measure credit card attributes.

\subsection{Social Status \& lifestyle}

A person's standing or disposition in relation to other people can be identified as the social status of an individual. It's vital to understand an individual's social impact in recent times. The comments given by family or friends for a product/service are more acceptable and credible than any other source (Kotler \& Keller, 2012). According to Wills \& Worthington (2006), social status is key a factor that stimulus on Consumer credit card usage. Similarly, Wickramasinghe \& Gurugamage (2009) found that credit limit and income level were directly link to credit card usage and utilizing credit cards as a short-term financing mechanism with a status symbol. Therefore, easier to control expenses, wealth factor, can purchase products over personal budgets, feel important and wealthy and feel cool and fashionable are considered dimensions to measure social status \& lifestyle.

\subsection{Psychographic Variables}

According to the prior research studies disclose that there were a few psychographic variables that impact attitude formation among Consumers. Time consciousness is considered as an important psychographic variable that effect on decision making and consumption. Feldman \& Hornik (1990) found that person's priorities govern their style. Similarly, Kassarjian \& Robertson (1991) found out psychographic variables impact credit card usage behavior. Therefore, attitude formation can be measured through attitude toward debt, peer group pressure (Cartwright \& Zander, 1968), self-esteem (DeRosis, 1973) and influence of advertisements (Batra \& Ray, 1986).

\subsection{Hypothesis Development}

In view of the above literature review referring to the most accepted models; independent variables are identified in the research study. Therefore, credit card attributes, social status \& lifestyle and Psychographic variables have been identified as the key independent variables that impact credit card usage behavior. 
H1: Credit card attributes have a positive relationship with consumer credit card usage behavior.

This emphasizes the credit card attributes such as convenience \& use patterns. Accordingly, this emphasizes that the consumers will be concerned about the advantages received when paying through credit card, extended credit limits, no need to take too much money, convenience when traveling overseas and safer to use for payments when paying higher amounts \& using for internet transactions.

\section{H2: Social status and lifestyle have a positive relationship with consumer credit card usage behavior.}

In here mainly the social status factor and lifestyle considered in detail for the credit card usage. According to the various lifestyles of the Consumers the credit card usage will differ. Usually high-end income \& middle-income consumers will tend to use more credit cards for their purchases. Consumers try to increase their living standards by using different types of products and services related to their living standards. So, there is a tentative situation of when there is higher social status, the consumer's tries to use their credit card more often for their requirements. Wealth factor feel cool and fashionable, expenditure controlling, and short-term financing factor would be directly linked to the social status and lifestyle.

H3: Psychographic variables have a positive relationship with consumer credit card usage behavior.

Mainly attitude toward debt, peer group pressure, time consciousness and impact on the advertisements would be considered as the variables here. These factors will give a direct impact to the consumer on using credit cards. As considering the advertisements regarding credit card offers would stimulate the consumer to spend in more, due to fact that, they can reward \& benefit more from the transactions. Also, in the meantime the peer group pressure will have a direct impact on spending on food, entertainment, accessories \& clothes. Which in turn the credit cards will be used to pay these bills by the Consumer.

\section{RESEARCH METHODOLOGY}

According to the comprehensive literature review and with reference to most accepted models identified, the following conceptual framework has been developed by identifying the independent and dependent variables. As shown in figure 1; credit card attributes, social status \& lifestyle and psychographic variables have been identified as the main independent variables that would have a direct impact on Sri Lankan consumer credit card usage behavior. 
Figure 1: Research Model

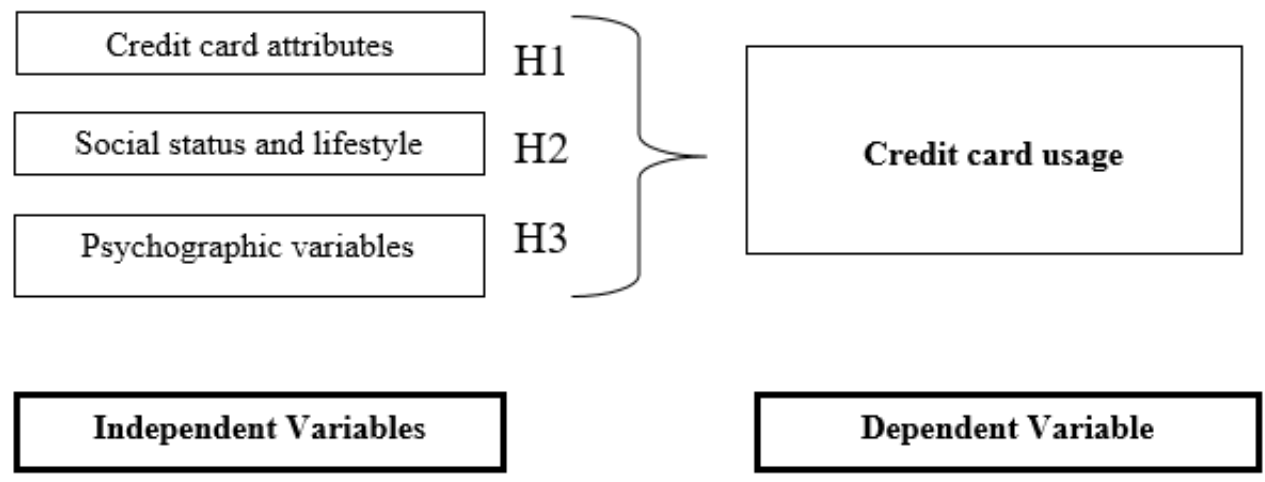

This research study is descriptive in nature and conducted to examine the factors impact Sri Lankan consumer credit card usage behavior. A questionnaire survey is used as the main method since it is a clear quantitative approach for the data gathering process. On the other hand, the literature review is used as a supplementary method to gather both qualitative and quantitative data. The gathered data is used to measure the relationship between the concept and variables.

This research has adhered to a non-probability sampling selection and the researcher has used the convenience sampling technique due to the limited budget, time and human resources to do this study. Therefore, a sample size of 100 respondents was closely monitored and chosen within the Western province, mainly in Colombo, Dehiwala, Maharagama and Kiribathgoda areas. The respondents demonstrated different limits of ages and fairly devised gender.

\subsection{Indicator of Concepts / Variables}

This research is based on the main concept of consumer credit card usage behavior. In order to measure this concept, the researcher has considered transaction patterns and usage of credit cards by the consumer. On the other hand, the variables were measured by using 13 different indicators of them, five are related to credit card attributes (advantages received when paying through credit card, extended credit limits, no need to take too much money, convenience when traveling overseas and safer to use for payments), four are covered in social status and lifestyle context (Wealth factor, feel cool and fashionable, expenditure controlling and short term financing), and the other four are stated as psychographic variables (attitude toward debt, peer group pressure, time consciousness and impact on the advertisements).

The closed-ended questions are consisting of the 5-point Likert scale (where 1 refers to the most important attribute and 5 refers to the least important attribute) and rank order type questions to get the level of agreement and the order of preference by the respondents respectively. After completing the 
data gathering process, SPSS is used to analyze the data critically and thereby test the hypotheses with specific data, leading to a confirmation (or not) of the original theory and arriving at a conclusion.

\section{RESULTS AND DISCUSSION}

The data presentation and analysis have been conducted based on the details gathered from the questionnaires. The data has been analyzed by using descriptive statistics, frequencies analysis and Pearson correlation analysis, and presented in the form of tables and narratives.

\subsection{Respondents Profiles}

Table 1: Respondents Profiles

\begin{tabular}{|c|c|c|c|}
\hline Detail & Category & Number & $\%$ \\
\hline \multirow[t]{2}{*}{ Gender } & Male & 56 & 56 \\
\hline & Female & 44 & 44 \\
\hline \multirow[t]{4}{*}{ Age } & $20-30$ & 36 & 36 \\
\hline & $30-40$ & 40 & 40 \\
\hline & $40-50$ & 16 & 16 \\
\hline & Above 50 & 8 & 8 \\
\hline \multirow[t]{4}{*}{ Occupation } & Private sector employee & 48 & 48 \\
\hline & Government employee & 30 & 30 \\
\hline & Businessman/woman & 16 & 16 \\
\hline & Other & 6 & 6 \\
\hline \multirow[t]{4}{*}{ Salary/Income } & Rs. $20,000-40,000$ & 16 & 16 \\
\hline & Rs. $40,000-70,000$ & 16 & 16 \\
\hline & Rs. $70,000-100,000$ & 36 & 36 \\
\hline & Rs. 100,000 - Above & 32 & 32 \\
\hline \multirow[t]{4}{*}{ Credit Limit } & Rs. $20,000-40,000$ & 28 & 28 \\
\hline & Rs. $40,000-70,000$ & 18 & 18 \\
\hline & Rs. $70,000-100,000$ & 20 & 20 \\
\hline & Rs. 100,000 - Above & 34 & 34 \\
\hline \multirow{4}{*}{$\begin{array}{lll}\text { Frequency of Credit } \\
\text { Card Usage }\end{array}$} & Once a month & 22 & 22 \\
\hline & Once a week & 40 & 40 \\
\hline & $2-3$ times per week & 32 & 32 \\
\hline & Everyday & 6 & 6 \\
\hline
\end{tabular}

As per table 1, the ratio of males in the target sample is $56 \%$ while $44 \%$ represents the female category. Therefore, the sample is fairly representative of the population targeted in the study. Further according 
to the above table, $40 \%$ of the target sample represent the age between 30 to 40 years. This is followed by ages 20 to 30 years and 40 to 50 years, which represents $36 \%$ and $16 \%$ respectively. Further, over 50 years has $8 \%$. Overall, $76 \%$ of the sample represents the youth and middle-aged segment in the Western Province region. As far as the above table is concerned, the majority of the sample represents private sector and government employees. $48 \%$ of the target sample represents the private sector employee category and 30\% represents the government employee category. There are also respondents who are businessman/woman \& entrepreneurs and other (households \& students) representing $16 \%$ and $6 \%$ of the sample respectively. Similarly, the majority of the sample represents Rs. $70,000-100,000$ salary range, where it is $36 \%$ of the target sample represents. The Rs. 100, 000 above salary range represents $32 \%$ of the target sample. Some respondents are within the salary range of Rs. 40,000 70,000 and Rs. 20, $000-40,000$ representing $16 \%$ and $16 \%$ of the sample respectively. About $34 \%$ of the target sample is having a credit limit of Rs. 100,000 above This is followed by Rs. 20,000 - 40,000 range and Rs. 70,000 - 100,000 range, with $28 \%$ and $20 \%$ respectively. Some respondents having a credit limit of Rs. 40, 000 - 70,000 which represents $18 \%$ of the total target sample. Overall, a majority of the target sample respondents are having higher credit limits. Finally, as per table 1, $40 \%$ of Consumers use credit cards once a week, while 32\% Consumers use credit card 2-3 times per week. There are also $22 \%$ of respondents who use a credit card once a month and the remaining $6 \%$ use a credit card every day.

\subsection{Descriptive Statistics}

Descriptive statistics define the basic characteristics of the variables of the sample.

Table 2: Descriptive Statistics

\begin{tabular}{|l|l|l|l|l|}
\hline Factor/ Component & Mean & $\begin{array}{l}\text { Standard } \\
\text { Deviation }\end{array}$ & Minimum & Maximum \\
\hline Credit Card attributes & & & & \\
\hline Discounts \& Rewards & 4.34 & 0.655 & 3 & 5 \\
\hline Extended credit & 3.20 & 0.899 & 1 & 5 \\
\hline Paying high value transactions & 3.52 & 0.810 & 2 & 5 \\
\hline Easiness of use & 3.92 & 0.825 & 2 & 5 \\
\hline Using for internet transactions & 3.70 & 0.905 & 1 & 5 \\
\hline & & & & \\
\hline Social status \& lifestyle & & & & \\
\hline Income level & 3.72 & 0.986 & 1 & 5 \\
\hline Feel cool and fashionable & 2.66 & 1.017 & 1 & 5 \\
\hline Plan for expenditure & 2.46 & 0.881 & 1 & 4 \\
\hline Short term financing & 4.12 & 0.742 & 1 & 5 \\
\hline & & & & \\
\hline Psychographic variables & & & & \\
\hline Peer group pressure & 2.98 & 0.953 & 1 & 4 \\
\hline Attitude toward debt & 3.08 & 0.895 & 1 & 5 \\
\hline Time consciousness & 3.74 & 0.774 & 2 & 5 \\
\hline Impact of advertisements & 3.68 & 0.839 & 1 & 5 \\
\hline
\end{tabular}


Descriptive statistics are shown based on 100 survey respondents. When analyzing the credit card attributes mean values; discounts \& rewards take the highest value of 4.34 . The second -best value is the easiness of use for overseas travel, with a mean value of 3.92. This is followed by using for internet (E-commerce) transactions, paying for high value transactions and extended credit limits with mean values of 3.92, 3.52 and 3.20 respectively. This information clearly says that consumers are looking for rewards and discounts when they purchase through credit cards. This is the common general scenario when it comes to Sri Lankan context of Consumers. This dimension is strongly evident from the fact that the minimum all the Consumers have marked as point 3 which is neutral. Credit cards using for internet transactions have grown significantly throughout last couple of years with the modern-day of transaction methods such as e-commerce. So usually Consumers using a credit card to pay for the transactions they have been committed through internet. Easiness of use for overseas traveling is a significant advantage that Sri Lankan consumers receive, due to our currency is not accepted in foreign countries for transactions. And it is easy to use with not much Hassel to take a large amount of cash in hand. So as mentioned above three dimensions are much accepted by the Consumers due to, they receive more favorable advantages and outcomes due to these are credit card attributes and ultimately these have a higher impact on credit card usage behavior. These three dimensions are strongly evident from the fact that the minimum all the Consumers have marked as point 2 which disagrees.

Social status and lifestyle variables emphasize how the social environment and Consumer perception about spending affects Consumer credit card usage behavior. The results in the above table show that short term financing (For emergency financing requirements) and income level/wealth of the Consumer makes a big impact on credit card usage behavior, as the mean values of the two dimensions are 4.12 and 3.72 respectively. This indicates that any shortage of cash arises in day to day expenses will be covered by the credit card. That means the Consumer can maintain his or her day today life in the same manner without affecting for their purchasing behaviors. Also, the income level would be highly desirable for the credit card usage due to the fact that with higher income levels the Consumer can bear up the credit card increasing balances when they use for transactions. These 2 dimensions are strongly evident from the fact that the maximum all the Consumers have marked as point 5 which is strongly agree. Feel cool and fashionable with spending for clothing \& entertainment and plan for future expenditure in the context of controlling expense mechanism has the least mean value of 2.66 and 2.46 respectively. Under the social status variable, it shows that spending high amount for fashion \& entertainment to feel cool and fashionable would be lies with the individual's cognitive feelings and behaviors. So, it would be widely differing from one Consumer to another, and this alone is not a habitual action by the majority of the respondents. Usually if you have a credit card most of the Consumers cannot control their existing expenses and future expenses. hence most of Consumers would be responding as disagree with these two statements. 
According to measure, the level of concern over psychographic variables, the mean values for time consciousness and impact of advertisements take the highest values of 3.74 and 3.68 respectively. The third best value is attitude toward debt, with a mean value of 3.08. Within the modern contest; the Consumers are more focused on doing a particular transaction as soon as possible. And in the meantime, there is a significant impact from the advertisements where the Consumers would be exposed to different types of print/social media and television media advertisements in day to day life. Attitude toward debt will be mainly considering upon having more than one credit cards and using all of those for the transactions. This mainly lies with the Consumer's willingness and ability to bear more credit. These three dimensions are strongly evident from the fact that the maximum all the Consumers have marked as point 5 which is strongly agree. Whereas peer group pressure is the least concerning aspect for the Consumers when it comes to credit card usage behavior. This shows that the Consumers are not that much modify their credit card usage behavior based upon their peer group pressure.

\subsection{Results of Reliability Statistics}

Cronbach Alpha reliability test was carried out as a test to measure internal consistency and reliability of the sample. According to Cortina (1993) Cronbach Alpha value of above 0.7 can be acceptable to conclude the variables are reliable. As per table 3, all the three independent variables have more than 0.7 , hence which can be considered as the measurement is reliable.

Table 3: Reliability Statistics

\begin{tabular}{|l|l|l|}
\hline Variable & Number of Components & Cornbach's Alpha \\
\hline Credit Card attributes & 5 & 0.714 \\
\hline Social status \& lifestyle & 4 & 0.739 \\
\hline Psychographic variables & 4 & 0.723 \\
\hline
\end{tabular}

\subsection{Analysis of Prominence of Variables}

Table 4: Prominence Variable Ranking

\begin{tabular}{|l|l|l|l|l|}
\hline Independent Variable & Number & Mean & $\begin{array}{l}\text { Standard } \\
\text { Deviation }\end{array}$ & Ranking \\
\hline Credit card attributes & 100 & 3.74 & 0.819 & 1 \\
\hline Social status and lifestyle & 100 & 3.24 & 0.905 & 3 \\
\hline Psychographic variables & 100 & 3.37 & 0.865 & 2 \\
\hline
\end{tabular}

The table 4 illustrates the level of importance of each independent variable. As per the results, credit card attributes are identified as the most prominent independent variable out of all variables that comes under the conceptual framework, as it gives the highest average score of 3.74. Psychographic variables have the second-highest average score 3.37. The least important independent variable is social status and lifestyle, as it has an average score of 3.24, which is the lowest among the independent variables. 


\subsection{Correlation}

Correlation significance between the variables were verified at the 5 percent significance level.

Table 5: Correlation Results

\begin{tabular}{|l|l|}
\hline Variable & Credit Card Usage Frequency \\
\hline Credit card attributes & $0.605^{*}$ \\
\hline Social status and lifestyle & $0.487 *$ \\
\hline Psychographic variables & $0.570^{*}$ \\
\hline
\end{tabular}

As per table 5, all independent variables of the study are significant at the 5\% level and have a positive relationship with credit card usage frequency. Credit card attributes have a value of 0.605 with credit card usage frequency which imply that there is a positive association between those 2 variables. Similarly, Social status and lifestyle and Psychographic variables have values 0.487 and 0.570 with credit card usage frequency respectively.

\subsection{Summary of Hypotheses Testing}

Table 6: Hypotheses Testing

\begin{tabular}{|l|l|c|}
\hline \multicolumn{2}{|c|}{ Hypotheses } & Result \\
\hline H1 & $\begin{array}{l}\text { There is a positive relationship between credit card attributes and } \\
\text { Consumer credit card usage behavior. }\end{array}$ & Supported \\
\hline H2 & $\begin{array}{l}\text { There is a positive relationship between social status \& lifestyle and } \\
\text { Consumer credit card usage behavior. }\end{array}$ & Supported \\
\hline H3 & $\begin{array}{l}\text { There is a positive relationship between psychographic variables and } \\
\text { Consumer credit card usage behavior. }\end{array}$ \\
\hline
\end{tabular}

It is clearly evident that all hypotheses developed under the conceptual framework are supported according to the Pearson correlation analysis and thereby accepted the model of research study.

\section{CONCLUSION}

The main objective of this research is to identify the factors influencing Consumer credit card usage behavior in the Sri Lankan context. There are also other objectives such as identifying the impact made by each factor, realizing the most prominent factors, the interrelationship between each factor and strategies for credit card issuers to implement. According to the research findings, all the factors considered under the conceptual framework have a positive relationship with the Consumer credit card usage behavior. However, the level of impact of each factor is different from one another. There are also sub-factors that have very strong influence on Consumer credit card usage behavior. All these factors need to be considered by credit card issuers and give special attention when marketing their credit card products. 


\subsection{Recommendations}

When looking at the data analysis, the advantages received when paying through credit cards become an important determinant in the Consumer credit card usage behavior. While in Sri Lanka, the people tend to change their buying behaviors when they received something extra. So, offering rewards and discounts when buying products through using credit cards would be having a significant impact to modify their behavior to use the credit card more frequently for purchases. Therefore, it is vital to offer more discounts and reward for the Consumers in order to increase the market sharer and Consumer loyalty towards the credit card issuer. Having additional credit limits would be influenced to use the credit card. Sometimes the credit card issuers study the credit history of the credit card holder and granting additional credit limits without further charge for their loyal Consumers so to retain more existing Consumers within the bank would be carefully analyzing the Consumers and vital to offer more credit limits. Sometimes the Consumers will be influenced to use credit cards due to, they would not necessarily carry large amount of cash for the transactions. And there is a security aspect as well. So, easiness and convenience factor more focused by the Consumers within the modern-day context.

Consumers also will be considering the acceptability of their card when they travel overseas and purchase products through their credit card in overseas. So, the credit card issuers need to expand the acceptability of the card by linking with more credit card networks such as master card and visa. And if the more merchants are willing to accept Consumer credit card would be having direct impact towards the Consumer satisfaction and retain the Consumer s within the credit card issuer.

Safer to use for the internet payments also will be a key dimension to use the credit card more often by new credit card users. As with the higher growth in e-commerce transactions, the payments also need to be done in a secure mode. So, using the credit card for these transactions will be having confidence among the buyers that this is a secure payment method. And in the other hand sellers also will be more supportive for credit card payments due to they can be guaranteed on the payments made by buyers.

Having higher disposable income levels would have direct significant impact to use credit cards more often. According to the data analysis also we can clearly see that the higher disposable income having higher credit limits and they tend to utilize their credit cards for the payments. So as credit card issuers need to focus on the Consumers disposable income levels before they would grant higher credit limits. As for the credit card issuers they need to more focus on issuing credit cards to the people who are well enough to bear the credit limits. Because otherwise the Consumer would be eventually defaulting the credit amount, and additional burden on the credit card issuer's P\&L as a bad debt. With the analysis of data, we can filter that; most of the people will be using their credit card for clothing and entertainment aspects. So, with the younger working generation of Sri Lanka tend to spend more on clothing and entertainment. So as for the credit card issuers it is vital to promote the credit card within 
young working professional crowd (age 20-30), because they spend more through credit card than the other age groups. Also give further additional merchant offers on clothing and entertainment for retain those Consumer groups and in order to acquire more prospective Consumers. The credit card will be sometimes used as a plan for future expenditures and can be used as backup funding for emergency payments such as sudden hospital charges. So as for the credit card issuers, they should sometimes need to offer additional credit limits as for the requirements of their Consumer for temporally. This would be a more successful strategy to retain the existing Consumers and acquire more new Consumers.

When considering psychographic variables have a moderate influence on credit card usage behavior when compared to the above 2 other variables. When considering advertising it is also important for public communications and helps build the equity of the credit card issuer's brand. According to the findings, people do not pay much attention to TV advertising for credit cards, as they are not exposed to the TV ads due to their busy lifestyles. Therefore, credit card issuers need to look for other options such as online marketing, social media awareness and panel displays to communicate their offers to Consumers. One strategy that they should implement is to display their offers, discounts and reward points in a panel near the point of sales machines and the entrance of the merchant store. Moreover, paper advertisement is also another low-cost strategy to keep the public informed and use themes such as benefits you get from paying through credit card paper advertisements to remind Consumers to use the credit card more often.

Sometimes there will be a strong influence to use the credit card more often, if the Consumers have several credit cards. So as for the credit card issuers, it is vital to issue supplementary cards for the same Consumer would be important when considering competition within the market and to acquire more interest income from the existing Consumers. According to the analysis, the peer group pressure would also be an influencing dimension to use the credit card, but it is not that much important for the credit card issuers when considering the credit card usage of the Consumers. This dimension will be considered when planning advertisement campaign for the credit card issues for new Consumers. Consumers also will be focused on the time taken to fulfill the deal. As with the credit card if they can do the purchases and deals quickly, they tend to use the credit card. As for the credit card issuers they need to offer the quick transaction processing and better transaction support on site for the Consumers. So, they can quickly process their deal.

\subsection{Limitations of the Research}

The following limitations were evident in the research study. The sample size for this research was 100 respondents, which does not represent the entire population. Further, the respondents are chosen by using a convenient sampling method and based on those findings the recommendations are given. Therefore, the bias in the research findings may have distorted the real market context. The research 
was conducted in some areas in the Western province only hence results could be different if the research was conducted in other parts of Sri Lanka. Finally, the factors considered under this study were based on the research model developed under a conceptual framework. There are many other factors could have influenced Consumer credit card usage behavior.

\subsection{Suggestions for Future Research}

As per the outcome of the findings and the limitation of the study, the following areas can be suggested for further research. Conduct a research to identify the factors influencing Consumer credit card usage behavior by using wider sample size which selects sample through identified Consumer clusters and conduct the same research for different areas of Sri Lanka. Carry out the same research by modifying the model in order to get more accurate outcomes.

\section{REFERENCES}

Amin, H. (2013). Factors influencing Malaysian Bank Consumers to choose Islamic credit cards: empirical evidence from the TRA model. Journal of Islamic Marketing, 4(3), 245-263. https://doi.org/1010.1108/JIMA-02-2012-0013.

Batra, R. \& Ray, M.L. (1986). Affective response mediating acceptance of advertising. Journal of Consumer Research, 13, 234-249.

Beardon, W.O., Teel, J.E. \& Durand, R.M. (1978). Media usage, psychographic and demographic dimensions of retail shoppers. Journal of Retailing, 54, 65-74.

Bernthal, M.J., Crockett, D. \& Rose, R.L. (2005). Credit cards as lifestyle facilitators, Journal of Consumer Research, 32, 130-145.

Cartwright, D. \& Zander, A. (1968). Group Dynamics: Research and Theory, Harper and Row, New York, NY.

Chan, R.Y. (1997). Demographic and attitudinal differences between active and inactive credit card holders - the case of Hong Kong. International Journal of Bank Marketing, 15(4), 117-125.

Cortina, J. M. (1993). What is coefficient alpha? An examination of theory and applications. Journal of applied psychology, 78(1), 98.

Devlin, J.F., Worthington, S. \& Gerrard, P. (2007). An analysis of main and subsidiary credit card holding and spending. International Journal of Bank Marketing, 25(2), 89-105.

De Rosis, L.E. (1973). Self-esteem, dignity or the sense of being. American Journal of Psychoanalysis, 23(1), 1627.

Durkin, T.A. (2000). Credit cards: use and consumer attitudes, 1970-2000. Federal Reserve Bulletin, 86, 623-634. 
Feinberg, R.A. (1986). Credit cards as spending facilitating stimuli: a conditioning interpretation. The Journal of Consumer Research, 13, 348-356.

Feldman, L.P. \& Hornik, J. (1990). The use of time: an integrated conceptual model. Journal of Consumer Research, 7, 407-419.

Foscht, T., Maloles, C., Swoboda, B. \& Chia, S. (2010). Debit and credit card usage and satisfaction: who uses which and why: evidence from Austria. International Journal of Bank Marketing, 28(2), pp. 150-165. https://doi.org/10.1108/02652321011018332.

Gan, L.L., Maysami, R.C. \& Koh, H.C. (2008). Singapore credit cardholders: ownership, usage patterns and perceptions. Journal of Services Marketing, 22(4), 267-280.

Garcia, G. (1980). Credit cards: an interdisciplinary survey. Journal of Consumer Research, 6, 327-337.

Goyal, A. (2006). Consumer perception towards the purchase of credit cards. Journal of Services Research, 6 , 179-190.

Griffiths, M. (2000). The sustainability of consumer credit growth in late twentieth century Australia. Journal of Consumer Studies \& Home Economics, 24(1), 23-33.

Hayhoe, C.R., Leach, L.J., Turner, P.R., Bruin, M.J. \& Lawrence, F.C. (2000). Differences in spending habits and credit use of college students. Journal of Consumer Affairs, 34, 113-133.

Hirschman, E.C. (1979). Differences in consumer purchase behavior by credit card payment system. The Journal of Consumer Research, 6, 58-66.

Holt, D.B. (1997). Poststructuralist lifestyle analysis: conceptualizing the social patterning of consumption in postmodernity. Journal of Consumer Research, 23, 326-350.

Jusoh Z.M. \& Lin LY. (2012). Personal financial knowledge and attitude towards credit card practices among working adults in Malaysia. International Journal of Business and Social Science, 3.

Kasarjian, H.H. \& Robertson, T.S. (1991). Perspective in Consumer Behavior, Scott Foresman, Glenview, IL.

Kaynak, E. \& Harcar, T. (2001). Consumers' attitudes and intentions towards credit card usage in an advanced developing country. Financial Services marketing, 6, 24-39.

Kaynak, E., Kucrukemiroglu, O. \& Ozmen, A. (1995). Correlates of credit card acceptance and usage in an advanced middle eastern country, Journal of Services Marketing, 9, 52-63.

Kotler, P. \& Keller, K.L. (2012). Marketing Management. 14th Edition, Pearson Education.

Lee, J. \& Hogarth, J.M. (1999). Returns to information search: consumer credit card shopping decision. Financial Counseling and Planning, 10, 23-34. 
Mathews, H.L. \& Slocum, J.W. (1986). Social class and commercial bank credit card usage. Journal of Marketing, 33(1), 71-79.

Meidan, A. \& Davos, D. (1994). Credit and charge card selection criteria in Greece. International Journal of Bank Marketing, 12(2), 36-44.

Park, H.J. \& Burns, L.D. (2005). Fashion orientation, credit card uses and compulsive buying. Journal of Consumer Marketing, 22(2-3), 135-142.

Pebe, M., Eze U.C., Yeow J.A. \& Lim K.P. (2012). Credit card use patterns among working adult in Batswana. International Journal on Social Science Economics \& Art, 2(2).

Phau, I. \& Woo, C. (2008). Understanding compulsive buying tendencies among young Australians: the roles of money attitude and credit card usage, Journal of Marketing Intelligence and Planning. 26(5), 441-460.

Safakli, O.V. (2007). Motivating factors of credit card usage and Ownership: Evidence from Northern Cyprus. Investment Management and Financial Innovations. 4(4).

Silvia, J. (2003). Consumer credit in a modern age, ABA Banking Journal, 95(6), 92.

Watkins, J.P. (2000). The corporate power and the evolution of consumer credit. Journal of Economic Issues, 34(4), 909-933.

White, K.J. (1975). Consumer choice and use of bank credit cards: a model and cross-section results. The Journal of Consumer Research, 2(1), 10-18.।

Wickramasinghe, V. \& Gurugamage, A. (2009). Consumer credit card ownership and usage practices: empirical evidence from Sri Lanka. International Journal of Consumer Studies, 33, 436-47.

Willis, M. \& Worthington, S. (2006). Foreign credit cards in China: to adapt or not to adapt. Journal of Asia Pacific Business, 7(3), 45-77.

Worthington, S., Stewart, D. \& Lu, X. (2007). The adoption and usage of credit cards by urban-affluent consumers in China, International Journal of Bank Marketing, 25(4), 238-250. 